\title{
Cytokine levels of interleukin-2 and 7 amongst antiretroviral therapy success and failure HIV patients attending the University Teaching Hospital, Yaoundé, Cameroon
}

\author{
George Mondinde IKOMEY ${ }^{1 *}$, Cedric HAPPI MBAKAM ${ }^{1}$, \\ Marie Claire Okomo ASSOUMOU ${ }^{1}$, Jacobs Graeme BRANDON², Martha MESEMBE ${ }^{1}$, \\ Emilia Lyonga MBAMYAH ${ }^{1}$, Edward MURPHY ${ }^{3}$ and Claude Tayou TAGNY ${ }^{4}$ \\ ${ }^{I}$ Center for the Studies and Control of Communicable Diseases (CSCCD), Faculty of Medicine and Biological \\ Sciences (FMBS), University of Yaoundé I, Cameroon. \\ ${ }^{2}$ Division of Medical Virology, Faculty of Medicine and Health Sciences, Stellenbosch University, Tygerberg, \\ South Africa. \\ ${ }^{3}$ University of California, San Francisco and Vitalant Research Institute, USA. \\ ${ }^{4}$ Department of Haematology, Yaoundé University Teaching Hospital, Cameroon. \\ "Corresponding author; E-mail: mondinde@yahoo.com; Box 8445, Yaoundé; Tel: +237674458197
}

\begin{abstract}
Immune reconstitution complications (IRC) are major problems faced by HIV treated patients worldwide. Interleukin (IL)-2 and IL-7 play vital roles in peripheral T-cell homeostasis. Our study objective was to measure and compare the blood plasma levels of IL-2 and IL-7 amongst antiretroviral therapy (ART) patients attending the Yaoundé University Teaching Hospital, Cameroon. We performed a cross-sectional study with 296 HIV positive patients enrolled between July 2017 and May 2018 at the Yaoundé University Teaching Hospital. IL-2, IL-7, T-cell profile counts and plasma viral load were measured on whole blood specimens. Data obtained were analyzed using Graph Pad Prism 5.0 and Epi info 7.0 Software. IL-2 and IL-7 plasma concentration levels were higher in patients with ART failure compared to ART success, with a mean \pm SD of $19.4 \pm 8$ and $17.1 \pm 6 \mathrm{pg} / \mathrm{ml}, 35.26 \pm 11$ and $21.5 \pm 5 \mathrm{pg} / \mathrm{ml}$, with $\mathrm{p}<0.001$ and $<0.001$. There was a direct and significant correlation between viral load, IL-2 and IL-7 with p values $=0.028$, and 0.020 , respectively. There was an association between IL-2, IL-7 and viral load in relation to the duration on treatment (DT), with $p$ values $=0.003\left(R^{2}=0.041, C I=0.069-0.34\right), 0.017\left(R^{2}=0.027, C I=-0.30-0.030\right)$, and $0.001\left(R^{2}=0.048, C I=\right.$ -0.047-0.76). Considering that limited surrogate markers are available for monitoring immune reconstitution and high associated mortality rates, IL-2 and IL-7 could be a good immunological predictor for ART failure and success in HIV infected individuals.
\end{abstract}

(C) 2020 International Formulae Group. All rights reserved.

Keywords: Homeostasis, Immune reconstitution, Interleukins, ART

\section{INTRODUCTION}

Antiretroviral therapy (ART) has significantly reduced AIDS-associated mortality by controlling viral replication and preventing severe immune suppression in HIV-infected patients. Approximately $66 \%$ of HIV diagnosed patients are receiving ART worldwide (Deeks et al., 2004). The 
monitoring of T-cell homeostasis is important for the management of HIV-infected patients on ART. Neglect in monitoring patient immunity could lead to Immune reconstitution complications (IRC) due to the exacerbation of opportunistic infections and other nonAIDS pathologies. It is known that about 10 $25 \%$ of HIV patients and about $20-40 \%$ coinfected patients on ART are at risk of developing IRC, with a high mortality rate of 2 - 3\% (Catalfamo et al., 2008; Lindi et al., 2010). Many countries have adapted to the recent diagnose and treat strategy proposed by WHO in 2017 that recommends the use of viral loads as standard markers for the monitoring of patients on ART (Katherine and Suzanne, 2001; Kinter et al., 2008). That approach does not consider the risk that could arise due to limited information on the homeostatic state of T-cells.

Studies have shown the involvement of interleukin-2 (IL-2) and IL-7 in HIV pathogenesis and their associated switch from T-helper type 1 (Th1) to T-helper type 2 (Th2) responses. IL-2 and IL-7 are known to play essential roles in peripheral $\mathrm{T}$-cell homeostasis and survival (Bruce and Andrew, 2012; Sébastien et al., 2017). Further studies have equally shown the use of these interleukins as immune adjuvants to help stabilize the homeostatic impact of T-cell as indicators of the T-cell immune response (Kinter et al., 2008; Bruce and Andrew, 2012)

IL-2 is a monomeric glycoprotein Type 1 cytokine produced by activated CD4+ and CD8+ T-cells. Its principal role is to stimulate the activation and proliferation of $\mathrm{T}$ lymphocytes and improve antigen processing, secretion and release of other cytokines $(\mathrm{Li}$, 2004). IL-7 is produced by stromal cells in the bone marrow, thymus and lymph node. They are important for T-cell thymopoiesis, and stimulation by IL-7 in the double-negative thymocytes leads to phosphorylation and inactivation of $\mathrm{Bad}$, a pro-apoptotic protein, which depends on the PI3K pathway (Dzhagalov et al., 2008).

There are many studies that have been performed in developing countries on the potential relevance of these cytokines in monitoring balance in T-cell homeostasis from patients on ART. In Cameroon, with a known high HIV diversity, no similar studies have been done. We hypothesis that IL-2 and IL-7 levels are higher in patients having treatment success in ART compared to failure and therefore are at risk of IRC. Our study aims to measure and compare the levels of IL2 and IL-7 as signal markers of immune reconstitution of T-cells amongst ART patients.

\section{MATERIALS AND METHODS Study design}

We performed a cross-sectional study with 296 enrolled HIV positive participants. They were enrolled between July 2017 and May 2018 at the Yaoundé University Teaching Hospital. All participants were consecutively recruited from daily consultation by physicians at the Internal Medicine unit at the Yaoundé University Teaching Hospital (YUTH).

\section{Study population}

The patients were classified into two groups: Treatment Success and Treatment Failure in proportions $81 \%$ and $19 \%$, using the 2016 WHO Classification (WHO, 2016) as follows: Treatment success $(\mathrm{VL}<1000 \mathrm{c} / \mathrm{ml}, \mathrm{CD} 4>500 / \mu \mathrm{l}$ and duration under ART > 6months,) and Failure (VL $>1000 \mathrm{c} / \mathrm{ml}$ with CD4 $<200 / \mu 1$ on ART above six months). Demographic characteristics and clinical information were collected for each participant using a standard questionnaire. These included age, sex, ART option and duration of ART. All treated patients were on the first-line ART regimen considering the country guidelines, which includes the combination of two nucleoside reverse transcriptase inhibitors (NRTIs), chosen among Zidovudine (AZT), Tenofovir (TDF) and Lamivudine (3TC) and a nonnucleoside reverse transcriptase inhibitor (NNRTI) being either Efavirenz (EFV) or Nevirapine (NVP). Ethical clearances for this study was obtained from the Cameroon National Ethical committee (reference number 044/CNE/SE/2017). Written and verbal 
informed consent was given by all participants The study was conducted according to the ethical guidelines and principles of the international Declaration of Helsinki 2013.

\section{Sample collection and analysis site}

Five $\mathrm{ml}(5 \mathrm{ml})$ of whole blood was collected in EDTA anticoagulant tubes at the sample collection unit of the Yaoundé University Teaching Hospital. Blood samples were transported and analyzed at the Center for the Study and Control of Communicable Diseases (CSCCD) of the Faculty of Medicine and Biomedical Sciences (FMBS), University of Yaoundé I, Cameroon. Plasma specimens were obtained after centrifugation of whole blood at a speed of $5000 \mathrm{rpm}$ for 5 minutes and stored in cryo-vials at $-20{ }^{\circ} \mathrm{C}$. Samples were analyzed within two months of the collection to avoid deterioration of cytokines over time.

\section{Measurement of cytokines levels}

Plasma levels of IL-2 and IL-7 were measured using quantitative sandwich Enzyme-linked Immune-Sorbent Assay (ELISA) kits (Invitrogen, Thermo Fisher Scientific, USA). A solid-phase ImmuneEnzymatic technique was used on a microtiter plate for the quantitative determination of IL2 and IL-7 in human plasma. Samples were analyzed according to the manufacturer's specifications. The absorbance was read using a spectrophotometer (Biotech ELx800, USA) set at a dual wavelength of 450- $550 \mathrm{~nm}$. Each sample was run in duplicate. The concentration of both interleukins was determined by extrapolating the results from a standard curve generated by plotting the average absorbance $(450-550 \mathrm{~nm})$ obtained for each standard level on the vertical (Y) axis compared to the corresponding IL-2 or IL-7 concentration on the horizontal (X) axis.

\section{Determination of CD4+ and CD8+ $T$ cells absolute count}

The measurement of CD4+ Tlymphocytes was done based on the principle of immunophenotyping. Fifty $\mu \mathrm{L}$ (50 ul) of whole blood was used for CD4 absolute cell counts, using the DB FACSCount reagent kit, and automated machine (BD Biosciences, San Jose, California, USA). Samples, including quality controls, were analyzed based on the manufacturers' guidelines.

\section{Determination of plasma HIV viral load}

Determination of the HIV load was performed using the Cobas Ampli prep / Cobas Taqman 96 platform (Roche Diagnostics, Branchburg, New Jersey, USA), per manufacturer's instructions. The detection limit was $<40$ copies $/ \mathrm{ml}$.

\section{Statistical analyses}

Data were analyzed using the Graph Pad PRISM 5.0 software package (Graph Pad Software Inc., La Jolla, California, USA) and Epi Info 7.0 software (Epi Info ${ }^{\mathrm{TM}}$ ). Comparisons between IL-2 and IL-7, within the different groups, were performed using the parametric student $\mathrm{T}$-test by evaluating their means and standard deviations. The correlations between IL-2, IL-7 and CD4+Tcells and HIV loads were established using the Pearson's correlation coefficient. Associations in duration on treatment time was done by using a regression coefficient and linear regression using their coefficient of determination. $\quad \mathrm{p}<0.05$ was considered statistically significant.

\section{RESULTS}

\section{Patient characteristics}

We enrolled 296 HIV infected patients of which $75.6 \%(n=224)$ were females and $24.4 \%(n=72)$ males. Their mean age $( \pm S D)$ was $41 \pm 10$ years. Patients were classified into two groups: Treatment Success $81 \%, \mathrm{n}=$ 244, and Treatment Failure 19\%, $(n=52)$ (Table 1).

\section{Cytokine levels of IL-2 and IL-7 amongst different groups of patients}

IL-2 and IL-7 concentration were higher in patients with ART Failure compared to ART Success, with a median of 16.08 and $12.68 \mathrm{pg} / \mathrm{ml} ; 37.63$ and $20.48 \mathrm{pg} / \mathrm{ml}$ with $\mathrm{p}=$ 0.0001 and 0.0001 respectively (Figure 1). 
This effect persisted after stratification by duration of treatment (Table 2).

\section{Correlation between Interleukins, CD4 and plasma HIV load}

There was a direct correlation between IL-2, IL-7 and viral load, with Pearson's correlation coefficient $r=0.16(p=0.0001,95 \%$ $\mathrm{CI}=0.065$ to 0.26$)$ and $\mathrm{r}=0.11(\mathrm{p}=0.028,95 \%$ $\mathrm{CI}=0.012$ to 0.21 ), respectively. The correlation was inversely significant between IL-2, IL-7 and CD4 count with Pearson's correlation coefficient $r=-0.29(p=0.0001,95 \%$ CI-0.38 to -0.20$)$ and $r=-0.32(\mathrm{P}=0.0001$,
$95 \% \mathrm{CI}=-0.41$ to -0.23$)$, respectively (Table 4).

Linear association between variables and treatment duration

There was a significant negative association between IL-2 and IL-7and viral load in relation to the duration on treatment (DT), with $\mathrm{p}$ value $=0.001\left(\mathrm{R}^{2}=0.077, \beta=-\right.$ $2.03,95 \% \mathrm{CI}=-2.72-(-1.33)), 0.003\left(\mathrm{R}^{2}=\right.$ $0.041, \beta=-0.08,95 \% \mathrm{CI}=-0.10-0.27)$ and $<0.0001\left(\mathrm{R}^{2}=0.048, \beta=-2047.45,95 \% \mathrm{CI}=\right.$ $2589.90-(-1525.01))$, respectively (Table 3$)$.

Table 1: Demographic and clinical characteristics of 296 enrolled participants at Yaoundé University Teaching Hospital between July 2017 and May 2018.

\begin{tabular}{|c|c|c|c|c|}
\hline \multicolumn{2}{|l|}{ Characteristics } & $\begin{array}{l}\text { Treatment } \\
\text { Failure }(n=52)\end{array}$ & $\begin{array}{l}\text { Treatment } \\
\text { Success }(n=244)\end{array}$ & $\begin{array}{l}\text { Total } \\
(n=296)\end{array}$ \\
\hline & & $\mathrm{n}(\%)$ & $\mathrm{n}(\%)$ & $\mathrm{n}(\%)$ \\
\hline \multirow{2}{*}{ Sex } & Males & $15(28)$ & $57(24)$ & $72(24)$ \\
\hline & Females & $39(72)$ & $185(76)$ & $224(76)$ \\
\hline \multirow{6}{*}{$\begin{array}{l}\text { Age }(\text { years }) \\
(\text { Mean } \pm \text { SD }=44 \pm 10)\end{array}$} & $20-30$ & $4(8)$ & $1(0.4)$ & $5(1.7)$ \\
\hline & $31-40$ & $29(50)$ & $88(36.9)$ & $117(39.5)$ \\
\hline & $41-50$ & $11(23.1)$ & $75(30.3)$ & $86(29)$ \\
\hline & $51-60$ & $10(19.2)$ & $56(24.6)$ & $76(25.6)$ \\
\hline & $61-70$ & 0 & $13(5.7)$ & $13(4.4)$ \\
\hline & $71-80$ & 0 & $9(2.5)$ & $9(3)$ \\
\hline \multirow{5}{*}{$\begin{array}{l}\text { ART } \\
\text { regiment }\end{array}$} & TENLAM-NVP & $25(46.2)$ & $138(56.6)$ & $162(55)$ \\
\hline & TENLAM-EFV & $24(46.2)$ & $72(29.5)$ & $96(32.4)$ \\
\hline & TENLAM-AZT & $2(3.8)$ & 0 & $2(0.7)$ \\
\hline & DUOVIR-N & $2(3.8)$ & $34(13.9)$ & $36(12)$ \\
\hline & $1-3$ & $16(30.8)$ & $78(32)$ & $94(32)$ \\
\hline \multirow{4}{*}{$\begin{array}{l}\text { Treatment } \\
\text { duration }(\text { years }) \\
(\text { mean } \pm \text { SD }=6 \pm 2)\end{array}$} & $4-6$ & $20(38.5)$ & $66(27)$ & $86(29)$ \\
\hline & $7-9$ & $10(19.2)$ & $70(28.7)$ & $80(27)$ \\
\hline & $10-12$ & $4(7.7)$ & $20(8.2)$ & $24(8)$ \\
\hline & $13-15$ & $2(3.8)$ & $10(4.1)$ & $12(4)$ \\
\hline
\end{tabular}



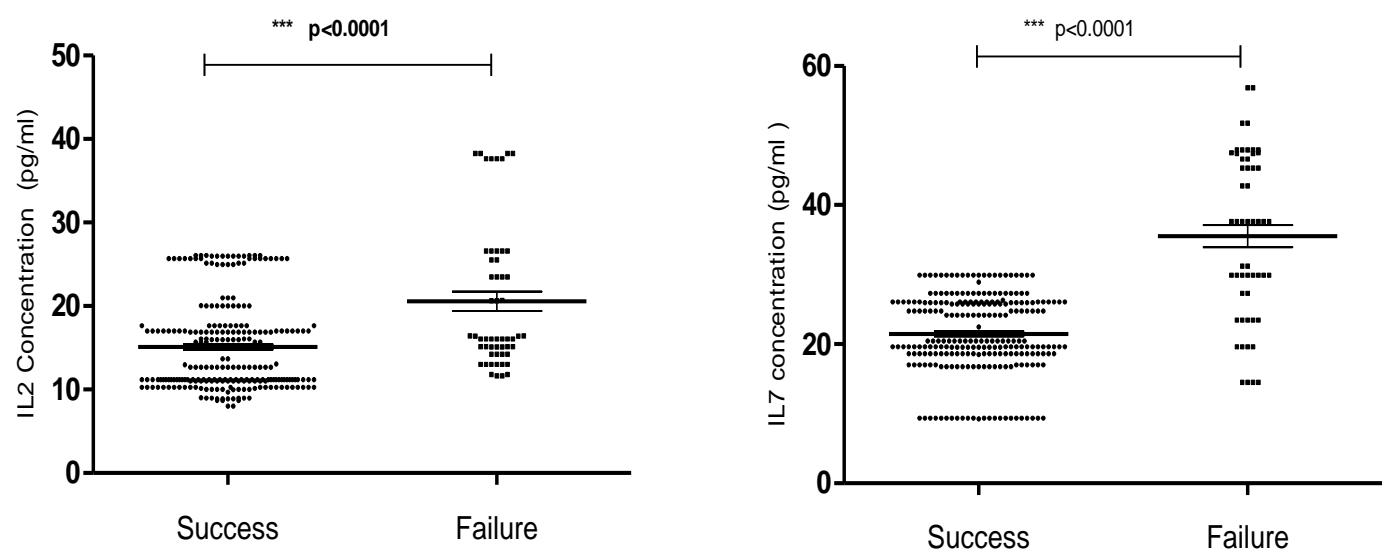

Figure 1: The dot plot illustrates the plasma levels of IL-2 and IL-7 in ART Failure and Success groups.

Table 2: The plasma levels of IL-2 and IL-7 and their linear association with treatment duration of the 296 ART patients.
IL7 (pg/ml)
IL2 (pg/ml)

\begin{tabular}{|c|c|c|c|c|c|c|}
\hline \multirow{3}{*}{$\begin{array}{l}\text { Treatment } \\
\text { Duration } \\
\text { (years) }\end{array}$} & \multirow{3}{*}{$\begin{array}{c}\text { Treatment } \\
\text { Failure } \\
(\mathbf{n}=52) \\
\text { Median } \\
\text { (Range) }\end{array}$} & \multirow{3}{*}{$\begin{array}{c}\text { Treatment } \\
\text { Success } \\
(\mathbf{n = 2 4 4 )} \\
\text { Median } \\
\text { (Range) }\end{array}$} & \multirow{3}{*}{$\begin{array}{c}\text { P- } \\
\text { value }\end{array}$} & \multirow[b]{2}{*}{$\begin{array}{c}\text { Treatment } \\
\text { Failure } \\
(\mathbf{n}=\mathbf{5 2})\end{array}$} & \multirow[b]{2}{*}{$\begin{array}{c}\text { Treatment } \\
\text { Success } \\
(\mathrm{n}=\mathbf{2 4 4})\end{array}$} & \multirow{3}{*}{$\begin{array}{c}\text { P- } \\
\text { value }\end{array}$} \\
\hline & & & & & & \\
\hline & & & & $\begin{array}{l}\text { Median } \\
\text { (Range) }\end{array}$ & $\begin{array}{l}\text { Median } \\
\text { (Range) }\end{array}$ & \\
\hline $1-3(n=94)$ & 19.6(14- 57) & $20.4(9-30)$ & 0.296 & $22.1(15-26)$ & $16(8-26)$ & 0.002 \\
\hline $4-6(n=86)$ & $44(23-52)$ & $18.6(9-27)$ & 0.0001 & $15.6(12-38)$ & $12(8-26)$ & 0.008 \\
\hline $7-9(n=80)$ & $46.6(29-47)$ & $24.2(16-30)$ & 0.0001 & $15.1(12-16)$ & $12.6(8-26)$ & 0.57 \\
\hline $10-12(n=24)$ & $32.6(17-38)$ & $25.9(20-30)$ & 0.325 & $20.6(13-37)$ & $21(10-25)$ & 0.06 \\
\hline $\begin{array}{c}13-15 \\
(n=12)\end{array}$ & $18.1(10-26)$ & - & - & - & $18(10-25)$ & - \\
\hline $\begin{array}{c}\text { Total } \\
(n=296)\end{array}$ & $31.16(10-57)$ & $17.6(9-30)$ & 0.0001 & $16(11-38)$ & $12.6(8-26)$ & 0.001 \\
\hline
\end{tabular}


Table 3: Linear association between the plasma levels of IL-2 and IL-7 and the treatment duration of the 296 ART patients.

\begin{tabular}{ccccc}
\hline \multirow{2}{*}{ Parameters } & \multicolumn{4}{c}{ Treatment Duration (TD) } \\
\cline { 2 - 5 } & IL7 & IL2 & CD4 & Viral Load \\
\hline $\mathbf{R}^{\mathbf{2}}$ & 0.077 & 0.041 & 0.062 & 0.048 \\
\hline P-value & $\mathbf{0 . 0 0 1}$ & $\mathbf{0 . 0 0 3}$ & $<\mathbf{0 . 0 0 0 1}$ & $<\mathbf{0 . 0 0 0 1}$ \\
\hline $\mathbf{9 5 \%} \mathbf{C I}$ & $-2.72-(-1.33)$ & $-0.10-0.27$ & $12.01-27.03$ & $-2589.90-(-1525.01)$ \\
$\boldsymbol{\beta}$ & $\beta=-2.03$ & $\beta=-0.08$ & $\beta=19.52$ & $\beta=-2047.45$ \\
\hline Equation & IL7 $=$ & IL2 $=$ & $\mathrm{CD} 4=$ & $\mathrm{VL}=$ \\
model & $38.12+(-2.03 * \mathrm{TD})$ & $16.38+(-0.08 * \mathrm{TD})$ & $387.64+19.52 * \mathrm{TD}$ & $20215.33+(-2047.45 * \mathrm{TD})$ \\
\hline
\end{tabular}

Table 4: Pearson Correlation between IL-2, IL-7, CD4 and plasma viral load using Pearson correlation coefficient amongst the 296 ART patients.

\begin{tabular}{|c|c|c|c|}
\hline & IL7 & IL2 & CD4 \\
\hline \multicolumn{4}{|l|}{ IL7 } \\
\hline IL2 & 0,054 & & \\
\hline CD4 & $-0,323 * *$ & $-0,288 * *$ & \\
\hline Viral load & $0,109^{*}$ & $0,162^{*}$ & $-0,583 * * *$ \\
\hline
\end{tabular}

\section{DISCUSSION}

We have evaluated the plasma levels of IL-2 and IL-7 from HIV Infected consented patients experiencing ART success and failure and compared their levels with HIV loads and CD4 cell counts. We have found that, IL-2 and IL-7 levels were higher in plasma of ART failure patients compared with success. We have also found a direct correlation between IL-2 and IL-7 and HIV viral loads with an inverse correlation with CD4. Information generated in this study may reinforce the usage of IL-2 and IL-7 as biomarkers for monitoring immune reconstitution in ART patients.

Our results could be explained based on the following hypothesis. 1) The involvement of IL-2 and-7 in the process of Activated Induce Cell Death (AICD) of T-cell death through signaling mediated by their common receptors (Li, 2004; Dzhagalov et al., 2008). 2) The pleiotropic nature of cytokines and their substantial involvement in maintaining homeostasis and survival of $\mathrm{T}$ cells relates to this role. 3) The up-regulation of specific cytokines like IL-2 and IL-7 has shown their commitment to T-cell activation, proliferation, lymphopoietic and survival plays major roles in immune reconstitution of T- cells (Chetoui, 2010; Corfe at al., 2011). 4) The variability of these cytokines in treated patients has suggested an alteration of their availability at various production and targets sites (Gougeon et al., 2002; Rethi et al., 2009; Chiodi et al., 2017).

The association of these cytokines with treatment success and failure may be attributed to the levels of IL-2 and IL-7 consumption influenced by the biology of CD4 T-cells during HIV pathogenesis. The cytokines transducer signals and multiple protein kinase pathways have been involved in this process. The balance between proliferation and apoptosis to regulate the size 
and diversity of mature naive and memory $\mathrm{T}$ cell pools in the peripheral circulation could also contribute (Meira et al., 2004; Silas et al., 2016).

Our results were similar to studies that have shown that IL-2 and 7 could not improve thymic activity, and may be responsible in the differences in levels within the different groups as it may instead enhance the expansion of cells already in the peripheral $\mathrm{T}$ cell pool (Terry et al., 2001; Huan et al., 2018). The levels of IL-7 remain stable over time and the intrinsic capacity of T-cells to respond to IL-7 signaling in vitro does not appear to diminish with time. Many other studies have also demonstrated the role of IL-2 and IL-7 in homeostasis of T-cells and response in modulating the equilibrium between proliferation and apoptotic cell death in mature naive and memory $\mathrm{T}$-cell subsets (Manu, 2015; Huan et al., 2018).

We have also found that there was a significant negative association between plasma levels of IL-2 and IL-7 and the duration after initiation on ART. Reduction in these cytokines after a long treatment is also consistent with these cytokines being markers of poor immunologic status. Our results also show higher levels of CD4 T-lymphocytes in participants with treatment success compare to treatment failure, as might be expected with immune reconstitution. It is known that HIV indirectly controls uninfected CD4 cells triggering them to apoptosis and destroying them after antigenic activation (Terry et al., 2001; Roger et al., 2012). However, the increase in CD4TL, as a result of the ART, is in part due to the blood trafficking of these cells, sequestered in the lymphatic compartment and increased production rate of circulating lymphocytes resulting from the expansion of peripheral T-cells, apoptosis suppression, and new T-cell production (Ohotu et al., 2015; Susana et al., 2017).

We recognize some limitations of this study. Firstly, we have not had prospective data on each participant due to the crosssectional study design. Secondly, we have not measured the adherence with ART, although we did have data on HIV viral load and CD4 count which may be surrogates for adherence.

\section{Conclusion}

Our findings have the relevance of identifying markers of immune reconstitution in HIV treated patients on ART. Further studies shall be required in similar cohorts in Africa to validate our preliminary findings. Considering that limited surrogate markers are available for monitoring immune reconstitution and high associated mortality rates, IL-2 and IL-7 could be an important immunological predictor for ART failure and success in HIV infected individuals.

\section{COMPETING INTERESTS}

The authors of this paper declare they have no competing interest for this work.

\section{ACKNOWLEDGEMENTS}

The authors thank the staffs of the Yaoundé University teaching hospital and the Centre for the Studies and Control of Communicable Diseases of the Faculty of Medicine and Biomedical Sciences of the University of Yaoundé 1; the ITAP and CV STARRN groups, for their support.

\section{AUTHORS' CONTRIBUTIONS}

CHM and GMI: Development of research concept, recruitment of patients, Laboratory analyses, interpretation of results and participated in the initial draft of the manuscript. GBJ and MCOA: Development of research concept, interpretation of results and drafting of manuscript. MM, CTT and EL contributed in laboratory analyses and drafting of the manuscript. All authors read and approved the final version of the manuscript.

\section{REFERENCES}

Anuska L, Jordi B, Arantxa G, Julià B, Cecilia C, Bonaventura C, José E. 2011. Interleukin-7 in Plasma Correlates with CD4 T-Cell Depletion and May Be Associated with Emergence of Syncytium-Inducing Variants in Human Immunodeficiency Virus Type 1Positive Individuals. Journal of Virology, 
75(21):

10319-10325.

DOI:10.1128/JVI.75.21.10319-

10325.2001

Bruce W, Andrew M. 2012. The T-Cell Response to HIV. Perspectives in Medicine., $\quad$ 2: $\quad$ a007054. DOI:10.1101/cshperspect.a007054

Catalfamo M, Mascio M, Hu Z, Srinivasula S, Thaker V, Adelsberger J. 2008. HIV infection associated immune activation occurs by two distinct pathways that differentially affect CD4 and CD8 T cells. Proc Natl Acad Sci USA., 105: 19851-19856.

DOI:

10.1073/pnas.0810032105

Chetoui N. 2010. Interleukin-7 promotes the survival of human CD4+ effector/memory $\mathrm{T}$ cells by up-regulating Bcl-2 proteins and activating the JAK/STAT signalling pathway. Immunology., $\quad \mathbf{1 3 0}(3)$ : $\quad 418-26$. DOI:10.1111/j.1365-2567.2009.03244.x

Chiodi F, Bekele Y, Lantto GR, Nasi A. 2017. IL-7 and CD4 T Follicular Helper Cells in HIV-1 Infection. Frontiers in Immunology., $\quad \mathbf{8}(451)$. DOI:10.3389/fmmu.2017.00451

Corfe S, Rottapel R, Paige C. 2011. Modulation of IL-7 thresholds by SOCS proteins in developing B lineage cells. Journal of Immunology., 187(7): 34993510.

DOI: https://doi.org/10.4049/jimmunol.11004 24

Deeks G, Kitchen C, Liu L, Guo H, Gascon R, Narvaez A. 2004. Immune activation set point during early HIV infection predicts subsequent CD4 + T-cell changes independent of viral load. Blood., 104(4): 942-947. DOI: 10.1182/blood-2003-093333

Dzhagalov I, Dunkle A, He Y. 2008. The antiapoptotic Bcl-2 family member Mcl-1 promotes $\mathrm{T}$ lymphocyte survival at multiple stages. J Immunol., 181(1): 5218. DOI: $10.4049 /$ jimmunol.181.1.521

Gougeon M, Lecoeur HP, Ledru E. 2002. Homeostasis and restoration of the immune system in HAART-treated HIVinfected patients: implication of apoptosis. HIV Infection., 251-268. DOI: 10.1002/047122393X.ch12

Huan X, Wei J, Xin Z, Ling Q, Bin S, Zhen L, Hao W. 2018. Elevated Level of CD4+ T Cell Immune Activation in Acutely HIV1-Infected Stage Associates With Increased IL-2 Production and Cycling Expression, and Subsequent CD4+ T Cell Preservation. Front. Immunol., 9(616).

DOI: https://doi.org/10.3389/fimmu.2018.006 16

Katherine K, Suzanne M. 2001. Cytokines and HIV-1: interactions and clinical implications. Antiviral Chemistry \& Chemotherapy., 12(3): 133-150. DOI: 10.1177/095632020101200301

Khaled A. 1999. Withdrawal of IL-7 induces Bax translocation from cytosol to mitochondria through a rise in intracellular pH. Proc Natl Acad Sci U S A., $\quad$ 96(25): $\quad 14476-81$. DOI:10.1073/pnas.96.25.14476

Kinter A, Godbout E, McNally J, Sereti I, Roby G, O'Shea M. 2008. The common gamma-chain cytokines IL-2, IL-7, IL15 , and IL-21 induce the expression of programmed death-1 and its ligands. $J$ Immunol., $\quad$ 181(10): 6738-46. DOI:10.4049/jimmunol.181.10.6738

Li W. 2004. Interleukin-7 inactivates the proapoptotic protein Bad promoting $\mathrm{T}$ cell survival. J Biol Chem., 279(28): 29160-6. DOI : 10.1074/jbc.M401656200

Lindi R, Jo-Ann P, Carolyn W, Francesca L, Lisa B, Koleka M, Salim AK. 2010. Plasma cytokine levels during acute HIV-1 infection predict HIV disease progression. AIDS., $\mathbf{2 4}(6)$ : 819-831. DOI:10.1097/QAD.0b013e3283367836

Manu I, Tanga M, Ndibugom I, Tohnain N, Tarla D. 2015. Effects of HIV/AIDSon Agricultural Production North West Region, Cameroon. Landmark Res J Agric Soil Sci., 2(1): 1-7. Retrieved from http://www.landmarkresearchjournals.or g/lrjass/index.php

Meira DA, Souza LR, Calvi SA, Lima CR, Henriques R, Pardini MI, MarcondesMachado J. 2004. Correlation between 
cytokine serum levels, number of CD4+ $\mathrm{T}$ cells $/ \mathrm{mm}^{3}$ and viral load in HIV-1 infected individuals with or without antiretroviral therapy. J. Venom. Anim. Toxins incl. Trop. Diseases., 10(3): 1678-9199. DOI: 10.1590/S167891992004000300008

Ohotu E, Onyemelukwe N, Odurukwe O, Ezema C. 2015. The relationship between IL-2 cytokine secretion and CD4 T-lymphocyte depletion in people living with HIV/AIDS, in Enugu, Nigeria. International Journal of Community Research., 4(4). Retrieved from

https://www.ajol.info/index.php/ijcr/artic le/view/148450

Rethi B, Vivar N, Sammicheli S, Chiodi F. 2009. Limited efficiency of endogenous interleukin-7 levels in $\mathrm{T}$ cell reconstitution during HIV-1 infection: will exogenous interleukin-7 therapy work? AIDS., 23: 745-55. DOI: 10.1097/QAD.0b013e3283298572

Roger P, Juan CL, Eduardo FC. 2012. The potential role of interleukin-2 in patients with HIV infection. AIDS reviews., 4(1), 36-40.

DOI:

https://www.researchgate.net/publication $/ 11371591$

Sara J, Louise S, Valérie D, Maryam B, Sandrina K, Naomi T. 2003. Homeostasis of Naive and Memory CD4+ T Cells: IL-2 and IL-7 Differentially Regulate the Balance Between Proliferation and Fas-Mediated Apoptosis. J Immunol., 171(1): 61-68. DOI:

https://doi.org/10.4049/jimmunol.171.1. 61

Sébastien P, Amit K, Georges H. 2017. Targeting TNF and TNF Receptor
Pathway in HIV-1 Infection: from Immune Activation to Viral Reservoirs. Viruses., $\quad$ 9(4): $\quad 64 . \quad$ DOI: 10.3390/v9040064

Silas LS, Abdoulmoumini M, Nzokem BK, Demano ML, Irene A. 2016. HIV/AIDS infection prevalence in an agriculturedominated rural community of west region of Cameroon. Asian Pac J Trop Dis., $\quad$ 6(10): 765-769. DOI: 10.1016/S2222-1808(16)61126-X

Susana LS, Adriana S, Paula M, Bénédicte M, Rémi C, Dário L, Rui MV. 2017. IL-7Induced Proliferation of Human Naive CD4 T-Cells Relies on Continued Thymic Activity. Front. Immunol., 8(20): 1-13. DOI: https://doi.org/10.3389/fimmu.2017.000 20

Terry J, Elizabeth C, Judith F, Michael M, David JL, John S, Crystal L. 2001. A potential role for interleukin-7 in T-cell homeostasis. BLOOD., 97(10): 29832990. Retrieved from http://www.bloodjournal.org/content/blo odjournal/97/10/2983.full.pdf?ssochecked=true

Thèze J. 2008. Les lymphocytes CD4 cibles et acteurs dans la pathogenèse de l'infection à VIH - Conséquences thérapeutiques. Bull Acad Natle Méd., 192(7): 1453-1468. Retrieved from: http://www.academie-medecine.fr/leslymphocytes-cd4-cibles-et-acteurs-dansla-pathogenese-de-linfection-a-vihconsequences-therapeutiques

WHO. 2016. WHO definitions of clinical, immunological and virological failure for the decision to switch ART regimens. Retrieved from https://www.who.int/hiv/pub/guidelines/ arv2013/art/WHO_CG_table_7.15.pdf 